Portland State University

PDXScholar

Environmental Science and Management

Faculty Publications and Presentations

Environmental Science and Management

10-30-2009

\title{
Similarity of Nutrient Uptake and Root Dimensions of Engelmann Spruce and Subalpine Fir at Two Contrasting Sites in Colorado
}

Melissa S. Lucash

Portland State University, lucash@pdx.edu

Ruth D. Yanai

SUNY College of Environmental Science and Forestry

Karis J. McFarlane

Lawrence Livermore National Laboratory

Sarah E. Kulpa

SUNY College of Environmental Science and Forestry

Dustin M. Wood

SUNY College of Environmental Science and Forestry

Follow this and additional works at: https://pdxscholar.library.pdx.edu/esm_fac

Part of the Natural Resources Management and Policy Commons, Other Ecology and Evolutionary

Biology Commons, and the Soil Science Commons

Let us know how access to this document benefits you.

\section{Citation Details}

Yanai, R. D., McFarlane, K. J., Lucash, M. S., Kulpa, S. E., \& Wood, D. M. (2009). Similarity of nutrient uptake and root dimensions of Engelmann spruce and subalpine fir at two contrasting sites in Colorado. Forest Ecology \& Management, 258(10), 2233-2241.

This Article is brought to you for free and open access. It has been accepted for inclusion in Environmental Science and Management Faculty Publications and Presentations by an authorized administrator of PDXScholar. Please contact us if we can make this document more accessible: pdxscholar@pdx.edu. 


\title{
Similarity of nutrient uptake and root dimensions of Engelmann spruce and subalpine fir at two contrasting sites in Colorado
}

\author{
Ruth D. Yanai $^{\mathrm{a}, *}$, Karis J. McFarlane ${ }^{\mathrm{a}, \mathrm{b}}$, Melissa S. Lucash ${ }^{\mathrm{a}}$, Sarah E. Kulpa ${ }^{\mathrm{a}, \mathrm{c}}$, Dustin M. Wood ${ }^{\mathrm{a}, \mathrm{d}}$ \\ a SUNY College of Environmental Science and Forestry, Syracuse, NY, United States \\ ${ }^{\mathrm{b}}$ Lawrence Livermore National Laboratory, Livermore, CA, United States \\ ${ }^{\mathrm{c}}$ Devine Tarbell \&' Associates, Inc., Syracuse, NY, United States \\ ${ }^{\mathrm{d}}$ Fountain Forestry, Tupper Lake, NY, United States
}

\section{A R T I C L E I N F O}

\section{Article history:}

Received 15 July 2008

Received in revised form 24 April 2009

Accepted 28 April 2009

\section{Keywords:}

Nutrient uptake kinetics

Ecosystem budget

Engelmann spruce

Subalpine fir

Loch Vale Watershed

Fraser Experimental Forest

Nitrate

Ammonium

Phosphate

Calcium

Magnesium

Potassium

\begin{abstract}
A B S T R A C T
Nutrient uptake capacity is an important parameter in modeling nutrient uptake by plants. Researchers commonly assume that uptake capacity measured for a species can be used across sites. We tested this assumption by measuring the nutrient uptake capacity of intact roots of Engelmann spruce (Picea engelmanni Parry) and subalpine fir (Abies lasiocarpa (Hook.) Nutt.) at Loch Vale Watershed and Fraser Experimental Forest in the Rocky Mountains of central Colorado. Roots still attached to the tree were exposed to one of three concentrations of nutrient solutions for time periods ranging from 1 to $96 \mathrm{~h}$, and solutions were analyzed for ammonium, nitrate, calcium, magnesium, and potassium. Surprisingly, the two species were indistinguishable in nutrient uptake within site for all nutrients $(P>0.25)$, but uptake rates differed by site. In general, nutrient uptake was higher at Fraser $(P=0.01,0.15,0.03$, and 0.18 for $\mathrm{NH}_{4}{ }^{+}, \mathrm{NO}_{3}{ }^{-}, \mathrm{Ca}^{2+}$, and $\mathrm{K}^{+}$, respectively), which is west of the Continental Divide and has lower atmospheric deposition of $\mathrm{N}$ than Loch Vale. Mean uptake rates by site for ambient solution concentrations were $0.12 \mu \mathrm{mol} \mathrm{NH}_{4}{ }^{+} \mathrm{g}_{\mathrm{fwt}}^{-1} \mathrm{~h}^{-1}, 0.02 \mu \mathrm{mol} \mathrm{NO}_{3}{ }^{-} \mathrm{g}_{\mathrm{fwt}}^{-1} \mathrm{~h}^{-1}, 0.21 \mu \mathrm{mol} \mathrm{Ca}^{2+} \mathrm{g}_{\mathrm{fwt}}^{-1} \mathrm{~h}^{-1}$, and $0.01 \mu \mathrm{mol} \mathrm{Mg}{ }^{2+} \mathrm{g}_{\mathrm{fwt}}^{-1} \mathrm{~h}^{-1}$ at Loch Vale, and $0.21 \mu \mathrm{mol} \mathrm{NH}_{4}^{+} \mathrm{g}_{\mathrm{fwt}}^{-1} \mathrm{~h}^{-1}, \quad 0.04 \mu \mathrm{mol} \mathrm{NO}_{3}^{-} \mathrm{g}_{\mathrm{fwt}}^{-1} \mathrm{~h}^{-1}$, $0.51 \mu \mathrm{mol} \mathrm{Ca}{ }^{2+} \mathrm{g}_{\mathrm{fwt}}^{-1} \mathrm{~h}^{-1}$, and $0.07 \mu \mathrm{mol} \mathrm{Mg}^{2+} \mathrm{g}_{\mathrm{fwt}}^{-1} \mathrm{~h}^{-1}$ at Fraser. The importance of site conditions in determining uptake capacity should not be overlooked when parameterizing nutrient uptake models.

We also characterized the root morphology of these two species and compared them to other tree species we have measured at various sites in the northeastern USA. Engelmann spruce and subalpine fir were indistinguishable in specific root length and diameter distribution, while most of the other 10 species had statistically distinct diameter distributions across five diameter classes $<2 \mathrm{~mm}$. Based on specific root length, subalpine fir and Engelmann spruce had significantly coarser roots than red pine (Pinus resinosa Soland), yellow birch (Betula allegheniensis Britt.), sugar maple (Acer saccharum Marsh.), chestnut oak (Quercus prinus L.), black cherry (Prunus serotina Ehrh.), and red spruce (Picea rubens Sarg.). White oak (Quercus alba L.), balsam fir (Abies balsamea (L.) Mill.), American beech (Fagus grandifolia Ehrh.) and loblolly pine (Pinus taeda L.) were intermediate in SRL (indistinguishable from Engelmann spruce and subalpine fir by ANOVA). Species that differ more in physiology and morphology than the two species we compared would likely show dissimilar uptake characteristics even at the same site.
\end{abstract}

(c) 2009 Elsevier B.V. All rights reserved.

\section{Introduction}

Nutrient uptake capacity, which describes uptake rates at the root surface as a function of solution concentration, is known to differ dramatically by species even when they are growing in similar conditions (Chapin et al., 1986). Uptake capacity for a given species may also vary depending on site conditions, notably nutrient availability. For example, roots exposed to high nutrient

\footnotetext{
* Corresponding author.

E-mail address: rdyanai@syr.edu (R.D. Yanai).
}

concentrations often have lower uptake capacity than roots exposed to low nutrient concentrations (Lee and Rudge, 1986; Siddiqi et al., 1989). Roots of quaking aspen (Populus tremuloides Michx.) grown under elevated $\mathrm{N}$ availability had lower $\mathrm{NH}_{4}{ }^{+}$and $\mathrm{NO}_{3}{ }^{-}$uptake capacities than those grown under ambient $\mathrm{N}$ (Rothstein et al., 2000). Uptake capacity of $\mathrm{NH}_{4}{ }^{+}$by Scots pine (Pinus sylvestris L.) was reduced following long-term fertilization experiments in Sweden (Jones et al., 1994). Ammonium uptake capacity by Norway spruce (Picea abies L.) decreased with increasing $\mathrm{N}$ inputs along a $\mathrm{N}$-deposition gradient in Europe (Högberg et al., 1998). This type of variation between species or between sites is not generally included in ecosystem models but 
could be important to predicting plant response to environmental change.

Species have inherent differences in root morphology as well as physiology, and these differences may contribute to differences in uptake capacity. American beech (Fagus grandifolia Ehrh.), yellow birch (Betula alleghaniensis Britt.) and sugar maple (Acer saccharum Marsh.) differed in their root diameter distributions and SRL at a field site in NH (Fahey and Hughes, 1994). Apple trees (Malus domestica Borkh.) have lower root length density and higher $\mathrm{P}$ uptake than citrus (Citrus paradisi Macf.) grown in the field (Bouma et al., 2001). Site factors can contribute to variation in root morphology as well. For example, roots grown under low nutrient conditions can be thicker and have a lower specific root length (SRL) than those grown under high nutrient conditions (Eissenstat, 1992; Fahey and Hughes, 1994).

Rocky Mountain subalpine forests are subjected to a range of $\mathrm{N}$ deposition rates, providing an opportunity to investigate the effects of varying levels of $\mathrm{N}$ deposition on nutrient uptake capacity. Subalpine forests on the east of the Continental Divide have total $\mathrm{N}$ deposition of $3-5 \mathrm{~kg} \mathrm{~N} \mathrm{ha}^{-1}$ year $^{-1}$ due to their proximity to anthropogenic $\mathrm{N}$ emissions from urban populations and animal husbandry operations (Baron et al., 2000; Rueth and Baron, 2002). Westside subalpine forests are protected from pollution affecting areas east of the Divide by wind patterns and the orographic effect of the mountains (Fenn et al., 2003), resulting in total $\mathrm{N}$ deposition of only $1-2 \mathrm{~kg} \mathrm{~N} \mathrm{ha}^{-1}$ year $^{-1}$ (Rueth and Baron, 2002). Eastside subalpine forests have higher foliar $\mathrm{N}$ concentrations, lower foliar and mineral soil C:N and lignin:N ratios, and higher net $\mathrm{N}$ mineralization potential in mineral soil (Baron et al., 2000). In addition, eastside forests have greater forest floor $\mathrm{N}$ concentrations and storage and higher $\mathrm{N}$ mineralization rates in forest floors than westside forests (Rueth and Baron, 2002). Finally, eastside lakes have demonstrated symptoms of eutrophication and disturbance and increased $\mathrm{NO}_{3}{ }^{-}$concentrations relative to westside lakes (Baron et al., 2000; Campbell et al., 2000).

We explored the hypotheses that nutrient uptake capacity differs among sites and species due to differences in (1) nutrient availability in different locations and (2) root morphology across species. We measured nutrient uptake in the field by intact roots of Engelmann spruce (Picea engelmanni Parry) and subalpine fir (Abies lasiocarpa (Hook.) Nutt.) at two sites in the Colorado Rocky Mountains with similar forest composition and structure but contrasting $\mathrm{N}$ deposition. We were thus able to test the effects of species and site on rates of uptake of $\mathrm{NH}_{4}{ }^{+}, \mathrm{NO}_{3}{ }^{-}, \mathrm{Ca}^{2+}, \mathrm{Mg}^{2+}$, and $\mathrm{K}^{+}$. To further explore the similarity in behavior of Engelmann spruce and subalpine fir, we compared specific root length and frequency distribution of root diameters of 12 tree species across seven sites.

\section{Methods}

\subsection{Site descriptions}

We measured nutrient uptake and collected roots from trees at two subalpine forests in central Colorado (Table 1 ). The vegetation at both sites is old-growth subalpine forest dominated by Engelmann spruce ( $P$. engelmanni) and subalpine fir (A. lasiocarpa). Engelmann spruce is longer lived than subalpine fir, and the spruce trees are generally older (400+ years, compared to 200+ years for fir) and bigger (Table 1) than the fir trees (Arthur, 1992). Vaccinium species dominate the understory of both sites. Soils at both sites have loamy textures and were formed in gravel and glacial till parent materials derived from gneiss and schist (Retzer, 1962; Stottlemyer et al., 1997). The sites experience similar climate, with long cold winters and short summers that are relatively cool and dry (Alexander et al., 1985; Arthur and Fahey, 1992). The main
Table 1

Site characteristics.

\begin{tabular}{lcc}
\hline Characteristic & Loch Vale & Fraser \\
\hline Latitude & $40^{\circ} 17^{\prime} \mathrm{N}$ & $39^{\circ} 54^{\prime} \mathrm{N}$ \\
Longitude & $105^{\circ} 39^{\prime} \mathrm{W}$ & $105^{\circ} 52^{\prime} \mathrm{W}$ \\
Elevation $(\mathrm{m})$ & 3100 & 3250 \\
MAP $(\mathrm{cm})$ & $100^{\mathrm{a}}$ & $82^{\mathrm{b}}$ \\
MAT $\left({ }^{\circ} \mathrm{C}\right)$ & $1.5^{\mathrm{a}}$ & $0.5^{\mathrm{c}}$ \\
Winter low $T\left({ }^{\circ} \mathrm{C}\right)$ & $-7.6^{\mathrm{a}}$ & $-10.3^{\mathrm{d}}$ \\
Summer high $T\left({ }^{\circ} \mathrm{C}\right)$ & $12.3^{\mathrm{a}}$ & $11.8^{\mathrm{d}}$ \\
Soil subgroup & Lithic Cryoboralf & Dystric Cryochrept $^{\mathrm{b}}$ \\
N deposition $\left(\mathrm{kg} \mathrm{N} \mathrm{ha}^{-1}\right.$ year $\left.^{-1}\right)$ & $4.1^{\mathrm{e}}$ & $1.7^{\mathrm{f}}$ \\
& & \\
Quadratic mean diameter $(\mathrm{cm})^{\mathrm{g}, \mathrm{h}}$ & $30.5(0.9)$ & $21.8(0.5)$ \\
$\quad$ Engelmann spruce & $15.5(0.9)$ & $13.3(1.6)$ \\
$\quad$ Subalpine fir & & $17.1(11.9)$ \\
Basal area $\left(\mathrm{m}^{2} \text { ha }^{-1}\right)^{\mathrm{h}}$ & $38.6(0.5)$ & $34.4(9.9)$ \\
$\quad$ Engelmann spruce & $26.9(9.7)$ & $679(61)$ \\
$\quad$ Subalpine fir & & $3334(371)$ \\
Stem density $($ stems ha & \\
$\quad$ Engelmann spruce & & \\
$\quad$ Subalpine fir & $1371(333)$ & \\
\hline
\end{tabular}

a Arthur and Fahey (1992).

b Alstatt and Miles (1983).

c Measured at Fraser Experimental Forest Headquarters (Stottlemyer and Troendle, 1992).

d Alexander et al. (1985).

e Annual average for 1992-1997 (Campbell et al., 2000).

f Calculated from data provided by Stottlemyer et al. (1997) for Lexen Creek Watershed for the 1990 water year.

g Diameter of the tree of mean basal area.

h Based on trees $>5 \mathrm{~cm}$ diameter surveyed in plots 8 and 16 at Loch Vale in 2002 (Mary Arthur, unpublished data) and plots LSC115 and LIP085 in 1991 and 1993 at Lexen (Wayne Shepperd, unpublished data). Standard errors are given in parentheses.

difference between sites is their proximity to anthropogenic $\mathrm{N}$ sources, which results in differences in atmospheric $\mathrm{N}$ deposition (Rueth and Baron, 2002). Across the region, about one-third of inorganic $\mathrm{N}$ deposition is in the form of $\mathrm{NH}_{4}{ }^{+}$with the remaining two-thirds as $\mathrm{NO}_{3}{ }^{-}$(Fenn et al., 2003).

Loch Vale Watershed, the site that receives greater rates of $\mathrm{N}$ deposition, is located high on the eastern slope of the Continental Divide in Rocky Mountain National Park, Colorado about $80 \mathrm{~km}$ northwest of Denver. Annual precipitation is $100 \mathrm{~cm}, 70 \%$ of which falls as snow. Total inorganic $\mathrm{N}$ deposition averaged $4 \mathrm{~kg} \mathrm{~N} \mathrm{ha}^{-1}$ year $^{-1}$ from 1992 to 1997 (Campbell et al., 2000). Soils are shallow loamy-skeletal, mixed, cryic Lithic Cryoboralfs, formed in glacial till on gneiss and schist bedrock. Our study is limited to the uneven-aged forest of Engelmann spruce and subalpine fir in the lower elevations $(\sim 3100 \mathrm{~m})$. Soil solution chemistry has been analyzed and is assumed the major source of available nutrients for vegetation at Loch Vale (Arthur and Fahey, 1993).

Fraser Experimental Forest, which receives less $\mathrm{N}$ deposition than Loch Vale, is located on the west slope of the Continental Divide, about $70 \mathrm{~km}$ west of Denver. Our measurements were made in Lexen Creek watershed near the old snow course site number 22. Wet inorganic $\mathrm{N}$ deposition at Lexen Creek watershed was $1.7 \mathrm{~kg} \mathrm{~N} \mathrm{ha}^{-1}$ year $^{-1}$ in 1990 (calculated from Stottlemyer et al., 1997); two other watersheds at Fraser Experimental Forest also averaged $1.7 \mathrm{~kg} \mathrm{~N} \mathrm{ha}^{-1}$ year $^{-1}$ for $1984-86$.

\subsection{Simulated soil solution}

The nutrient solutions we used during uptake experiments were based on soil solution chemistry for Loch Vale (Arthur and Fahey, 1993); soil solution concentrations were not available for Fraser. Using this approach makes it possible to compare the 
behavior of roots between the two sites at common initial concentrations. To ensure that nutrients were available in high enough concentrations for measurable uptake to occur and to determine uptake as a function of concentration, roots were exposed to the simulated soil solution $(1 \times)$ or to a solution of five $(5 \times)$ or ten $(10 \times)$ times the simulated soil solution concentrations. The range of actual concentrations used in the field in our $1 \times$ solutions at the two sites was 3-22 $\mu \mathrm{M} \mathrm{NH}_{4}{ }^{+}, 4-9 \mu \mathrm{M} \mathrm{NO}_{3}{ }^{-}, 50-$ $81 \mu \mathrm{M} \mathrm{Ca}^{2+}, 8-11 \mu \mathrm{M} \mathrm{Mg}^{2+}$, and $10-25 \mu \mathrm{M} \mathrm{K}^{+}$as measured in control tubes, described below. Concentrations in $5 \times$ and $10 \times$ solutions were proportionately higher (averages are shown in Fig. 1). We included $\mathrm{PO}_{4}{ }^{3-}, \mathrm{Na}^{+}$, and $\mathrm{Al}^{3+}$ in the simulated solutions, but these were not analyzed for uptake. We adjusted the $\mathrm{pH}$ of our solutions in the field, if necessary, to mimic the reported $\mathrm{pH}$ of 4.95.0 (Arthur and Fahey, 1993).

\subsection{Uptake experiments}

Uptake experiments were conducted at Loch Vale from June 22 to 25 and at Fraser from June 27 to 30, 2001. At each site, we excavated small branches of roots of each species, leaving them attached to the tree. Species were identified by tracing each root back to a tree or to a root coarse enough to have distinguishing bark characteristics. The roots were washed with distilled water to remove soil particles and placed in a tube containing $30 \mathrm{ml}$ (Loch Vale) or $27 \mathrm{ml}$ (Fraser) of nutrient solution. The solutions were aerated to provide roots with $\mathrm{O}_{2}$ and to prevent depletion zones from forming around the roots. Tubes were sealed with Parafilm and covered with tarps to minimize evaporation and contamination. We did not use a pre-treatment period in these experiments. Roots were used in multiple experiments, as follows. At Loch Vale, 10 roots were measured for 4 and $96 \mathrm{~h}$ and 11 roots were measured for 2, 24, and $44 \mathrm{~h}$. At Fraser, 7 roots were measured for 2, 66 and $4 \mathrm{~h}$, and 5 roots were measured for 1,20 , and $22 \mathrm{~h}$. The initial solution concentrations $(1 \times, 5 \times$, and $10 \times)$ were applied to roots within each experiment, and the roots received the same nutrient treatment in subsequent experiments. Tubes with aerated solution and no roots served as controls (two for each concentration and duration at Loch Vale; one for each concentration and duration at Fraser). At the end of each experiment, solution samples were measured for volume and filtered using $0.4 \mu \mathrm{m}$ polycarbonate filters. Samples were frozen upon returning from the field each day.

Solution samples were analyzed for $\mathrm{NO}_{3}{ }^{-}$and $\mathrm{NH}_{4}{ }^{+}$by continuous flow analyzer (model AA3; Bran and Luebbe, Norderstedt, Germany). Not all the samples were analyzed for $\mathrm{NO}_{3}{ }^{-}$; results for the $10 \times$ nutrient solution concentrations for Fraser are therefore not reported. Concentrations of $\mathrm{Ca}^{2+}, \mathrm{Mg}^{2+}, \mathrm{K}^{+}$, and $\mathrm{Al}^{3+}$ were measured using inductively coupled plasma emission spectroscopy (model FMA-03, Spectro Analytical Instruments, Kleve, Germany).

\subsection{Root analysis}

After experiments were completed, the roots were severed and returned to the lab, where they were stored in alcohol. They were



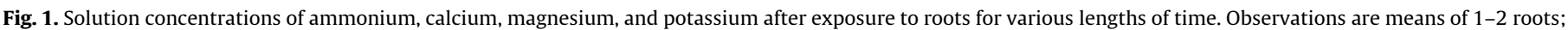


squares for Fraser and filled squares for Loch Vale, increasing in size from $1 \times$ to $10 \times$. 
weighed wet before they were analyzed for length and surface area. Each root branch was analyzed separately. We cut the roots into small pieces and oriented them in the direction of the scan to minimize shadows in the image. The roots were spread in a tray of water on a flatbed scanner, and scanned at a resolution of $600 \mathrm{dpi}$ using transmitted, not reflected, light. The image was converted to a bitmap (black and white) using an automated threshold, to avoid operator bias. Stray pixels were removed with a 2-pixel noise filter. The final images were analyzed with software from Delta-T Scan. We defined diameter classes for scanning as follows: $\leq 0.1,0.1-0.2$, $0.2-0.5,0.5-1.0,1.0-2.0$, and $>2.0 \mathrm{~mm}$. Root sections with diameters $>2 \mathrm{~mm}$ were removed after scanning and the $<2 \mathrm{~mm}$ roots were dried at $65^{\circ} \mathrm{C}$ and weighed. Specific root length (SRL) of the $<2 \mathrm{~mm}$ root fraction was calculated as total length divided by dry weight. We analyzed root weight and SRL across species and sites using ANOVA in SAS.

For comparison to the roots from Loch Vale and Fraser, we present the results of the same analysis of 10 other species collected at five additional sites. Some of these other experiments have been described elsewhere (Lucash et al., 2005; McFarlane and Yanai, 2006), but none of the root dimensions have been previously reported. The number of roots analyzed from each site and species varied, as follows: Hubbard Brook Experimental Forest, New Hampshire ( 5 balsam fir (Abies balsamea (L.) Mill.), 6 red spruce (Picea rubens Sarg.), 8 American beech and 7 yellow birch); Huntington Forest, New York (17 American beech and 10 sugar maple); Turkey Hill Plantation, New York (12 black cherry (Prunus serotina Ehrh.) and 8 red pine); Calhoun Experimental Forest, South Carolina (59 loblolly pine (Pinus taeda L.)); and Walker Branch, Tennessee ( 7 chestnut oak (Quercus prinus L.) and 6 white oak). The numbers of root branches analyzed from our Colorado sites were 9 Engelmann spruce and 12 subalpine fir at Loch Vale and 5 Engelmann spruce and 6 subalpine fir at Fraser.

The root distribution data were analyzed by root branch, because the individual observations of proportion within a size class were not independent within root branch. Multivariate analysis of variance was conducted using the General Linear Models procedure in SAS (SAS Institute Inc., 2004). Contrasts between species within a diameter class were evaluated using the Waller-Duncan $K$-ratio $t$-test, based on the $<2 \mathrm{~mm}$ portion of the root branch. We also identified species that differed in the proportion of root length in at least one diameter class.

\subsection{Data analysis}

Uptake was calculated from the change over time in the amount of nutrient in the tube, calculated as the product of concentration and volume. The same calculation was made for control tubes (without roots) and these differences were subtracted from the changes observed for roots. Control concentrations did not differ with duration of the experiment, so we used the means of control "uptake" for each site and solution concentration. The average loss of solution volume averaged $7 \%$ in roots and $3 \%$ in control tubes $(1-2 \mathrm{ml})$ and did not differ by site $(P=0.36)$. Uptake rates are reported in units of micrograms of nutrient per gram fresh root per hour. We used fresh weight because it was as good a predictor of uptake as dry weight, length or surface area (McFarlane and Yanai, 2006) and because not all of our roots were scanned.

We used analysis of variance with repeated measures to reflect the use of the same roots in multiple experiments. We assessed the effect of site (two levels), species (two levels), initial nutrient solution concentration (three levels), duration of the experiments (nine levels), and their interactions on the final concentrations and calculated uptake rates of $\mathrm{NH}_{4}^{+}, \mathrm{Ca}^{2+}, \mathrm{Mg}^{2+}$ and $\mathrm{K}^{+}$, using proc mixed in SAS. When interactions including site or species effects were significant at a $0.1 \alpha$ level, we conducted slicing tests and multiple comparisons tests using a Tukey adjustment to interpret those interactions. We intended to analyze $\mathrm{PO}_{4}{ }^{3-}$ uptake, but this was not possible because the initial solution concentrations were very low, and solutions exposed to roots proved indistinguishable in concentration from controls.

We also computed average uptake rates for 2-h experiments at each of the three initial solution concentrations. We report these by site but not by species, since species did not differ significantly in uptake rates.

\section{Results}

\subsection{Roots deplete nutrients in simulated soil solutions}

We observed progressive nutrient uptake over time: final nutrient concentrations in solutions exposed to roots in the field were generally lower in tubes that held roots for longer time intervals (Fig. 1). For $\mathrm{K}^{+}$, however, the concentrations measured after applying the solutions were generally greater than $100 \%$ of the initial solution concentrations, indicating that nutrient efflux exceeded nutrient uptake.

For $\mathrm{NH}_{4}{ }^{+}$, uptake exceeded efflux for every root and time interval measured, and concentrations declined rapidly over time (Fig. 1). Ammonium concentrations at Fraser, the more N-limited site, declined more rapidly than at Loch Vale. Within a day or two, the solutions in the $5 \times$ and $10 \times$ treatments were drawn down to about the $1 \times$ level, the concentration of $\mathrm{NH}_{4}{ }^{+}$in soil solution reported by Arthur and Fahey (1993). This observation suggests that the ambient solution concentrations may be controlled in part by the minimum concentration for root uptake.

Declines in concentrations of the divalent cations $\mathrm{Ca}^{2+}$ and $\mathrm{Mg}^{2+}$ were similar in their behavior (Fig. 1). Concentrations depleted very gradually over time, relative to initial conditions (controls without roots). Unlike $\mathrm{NH}_{4}{ }^{+}$, differences among the $1 \times, 5 \times$, and $10 \times$ treatments persisted over the three or four days of our longest experiments. Clearly, roots did not take up these ions to the minimum concentration for root uptake. It appears that $\mathrm{Ca}^{2+}$ and $\mathrm{Mg}^{2+}$ are available in excess of tree demand, unlike $\mathrm{NH}_{4}^{+}$, consistent with limitation by $\mathrm{N}$. However, concentrations were generally lower at Fraser than at Loch Vale, indicating more rapid uptake of $\mathrm{Ca}^{2+}$ and $\mathrm{Mg}^{2+}$ at the more nutrient-limited site.

Nitrate concentrations, like those of $\mathrm{Ca}^{2+}$ and $\mathrm{Mg}^{2+}$, were not rapidly depleted (Fig. 1). Concentrations in the $5 \times$ and $10 \times$ treatments remained relatively high, unlike $\mathrm{NH}_{4}{ }^{+}$concentrations. The exception was the 96-h experiment, where depletion was more complete than expected based on the shorter experiments. Recall that the observations for each experimental duration represent the end point of an experiment, rather than the progress over time of a single exposure. The rate of uptake over $96 \mathrm{~h}$ is not as impressive as suggested by the log scale, but is similar to that at 44 and $66 \mathrm{~h}$ (Fig. 2).

Potassium (Fig. 1) had consistent net nutrient efflux across all treatments, at least initially. After about a day of net $\mathrm{K}^{+}$efflux, concentrations were reduced (net uptake occurred) but not to levels much below the initial simulated soil solution. Like $\mathrm{Ca}^{2+}$ and $\mathrm{Mg}^{2+}$, solution concentrations of $\mathrm{K}^{+}$were generally higher at Loch Vale than at Fraser.

\subsection{Uptake rates}

Uptake rates were calculated using the concentration and volume of solutions at the beginning and end of each experiment, subtracting the values from the controls (tubes without roots). These rates reflect the average for the duration of each experiment; they also take into account the measured mass of each root (Fig. 2). 



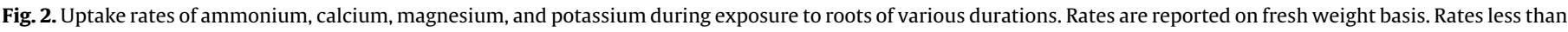
zero indicate net efflux.

Uptake rates of all nutrients were indistinguishable between spruce and fir $\left(P=0.11\right.$ for $\mathrm{NO}_{3}{ }^{-}$and $P>0.32$ for other ions $)$ in a repeated-measures analysis of variance including species, site, initial solution concentration, and duration of the exposure. Uptake rates were generally higher at Fraser than at Loch Vale, most significantly for $\mathrm{NH}_{4}{ }^{+}(P=0.01)$ and less so for $\mathrm{NO}_{3}{ }^{-}(P=0.15)$ and $\mathrm{K}(0.18)$. Uptake of $\mathrm{Ca}^{2+}$ was significantly greater at Fraser than at Loch Vale only at the $10 \times$ nutrient solution concentration $(P<0.01)$, resulting in an interaction of site and initial solution concentration $(P<0.01)$. For $\mathrm{Mg}$, uptake rates were higher at Fraser only at ambient solution concentrations $(P=0.14)$ and were higher at Loch Vale under the $5 \times$ nutrient solution $(P=0.03)$ and not different among sites at the highest solution concentration $(P=0.27)$.

Uptake rates were higher at higher concentrations, especially in short-term exposures (Fig. 2), resulting in significant interactions with the duration of the experiments. In repeated-measures ANOVA the main effect of initial solution concentration was important for $\mathrm{Ca}^{2+}$ and $\mathrm{Mg}^{2+}$ uptake $(P<0.01)$ and $\mathrm{NH}_{4}{ }^{+}$uptake $(P=0.06)$ but not for $\mathrm{K}^{+}$efflux or $\mathrm{NO}_{3}{ }^{-}$uptake $(P>0.50)$. There were no significant three-way interactions.

Uptake rates differed significantly with the duration of the experiments for all nutrients $(P<0.01)$. Specifically, nutrient uptake (averaged over the time period) declined over longer periods (Fig. 2). For $\mathrm{NH}_{4}{ }^{+}$, this decline could conceivably be attributed to the progressive depletion of nutrients from the solutions (Fig. 1), but for base cations, the concentrations in $5 \times$ and
$10 \times$ treatments were still high at the end of long experiments (Fig. 1). The consistent near-zero uptake rates of base cations in long experiments show that uptake was not a consistent function of nutrient concentration over four days, but declined with time.

Because of the declining uptake rates in longer experiments, we used the 2-h experiments as the best representation of uptake by roots in situ. In general, uptake rates increased with solution concentration and were higher at Fraser than Loch Vale (Table 2). We averaged uptake rates by Engelmann spruce and subalpine fir because they were statistically indistinguishable and numerically similar.

\subsection{Root morphology}

Engelmann spruce and subalpine fir were remarkably similar in root morphology (Fig. 3). The specific root length (length per unit mass) was $8.8 \mathrm{~m} \mathrm{~g}^{-1}$ for Engelmann spruce and $7.5 \mathrm{~m} \mathrm{~g}^{-1}$ for subalpine fir (Fig. 4). Analysis of variance showed that neither species $(P=0.34)$ nor site $(P=0.29)$ differences were significant.

Engelmann spruce and subalpine fir were the two coarsest root systems of the 12 species we studied (Fig. 4). Red pine, yellow birch, sugar maple, chestnut oak, black cherry, and red spruce had significantly finer roots (higher SRL). White oak, balsam fir, American beech and loblolly pine were intermediate in SRL (indistinguishable from Engelmann spruce and subalpine fir by ANOVA). We expected congeneric species to have similar SRL, but this was not generally true. Engelmann spruce had significantly 


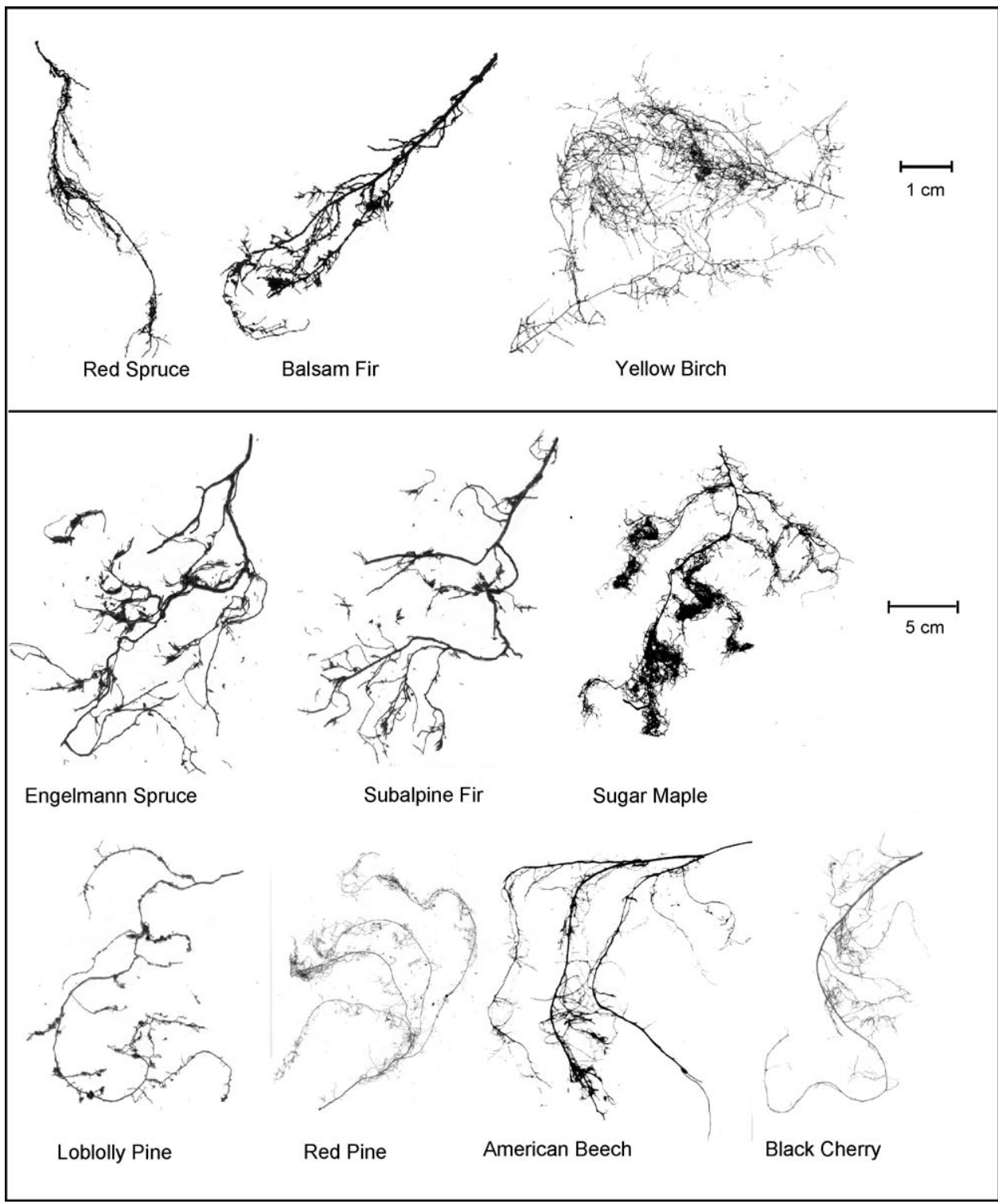

Fig. 3. Morphology of representative root branches used in nutrient uptake experiments.

coarser roots than red spruce, and loblolly pine had significantly coarser roots than red pine (Fig. 4).

Frequency distributions of fine root diameters (Fig. 5) support the similarity of Engelmann spruce and subalpine fir. Consistent with low SRL, these species have as much or more root length in the $0.5-1 \mathrm{~mm}$ diameter class than in the $0.2-0.5 \mathrm{~mm}$ class. For most of the other species, the diameter class with the greatest root length was the $0.2-0.5$ class. In all species, the two smallest size classes $(<0.2 \mathrm{~mm})$ accounted for less of the root length than the next two size classes (0.2-1 mm), and the amount of root length in the 1$2 \mathrm{~mm}$ size class was less than in the $0.5-1 \mathrm{~mm}$ size class.

\section{Discussion}

\subsection{Magnitude of uptake rates}

Ammonium uptake rates in this study were slightly lower than rates reported for other tree species. Ammonium uptake in our

Table 2

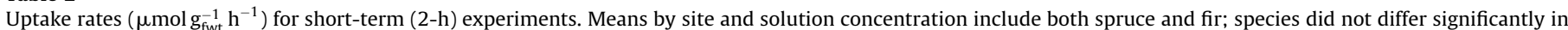

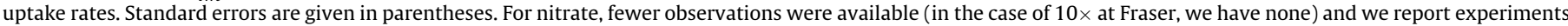
up to $4 \mathrm{~h}$ in duration.

\begin{tabular}{|c|c|c|c|c|c|c|c|}
\hline Site & Concentration & $n$ & $\mathrm{NH}_{4}^{+}$ & $\mathrm{NO}_{3}^{-}$ & $\mathrm{Ca}^{2+}$ & $\mathrm{Mg}^{2+}$ & $\mathrm{K}^{+}$ \\
\hline Loch Vale & $1 \times$ & 4 & $0.07(0.01)$ & $0.023(0.008)$ & $18(0.11)$ & $0.02(0.004)$ & $-0.47(0.13)$ \\
\hline Fraser & $1 \times$ & 2 & $0.17(0.02)$ & $0.027(0.013)$ & $47(0.15)$ & $0.07(0.03)$ & $-0.57(0.05)$ \\
\hline Loch Vale & $5 \times$ & 4 & $0.18(0.04)$ & $0.024(0.013)$ & $63(0.33)$ & $0.12(0.04)$ & $-0.26(0.2)$ \\
\hline Fraser & $5 \times$ & 3 & $0.24(0.06)$ & $0.37(0.16)$ & $55(0.15)$ & $0.04(0.03)$ & $-0.43(0 . .09)$ \\
\hline Loch Vale & $10 \times$ & 2 & $0.36(0.12)$ & $0.34(0.01)$ & $00(0.54)$ & $0.26(0.05)$ & $-0.38(0.14)$ \\
\hline Fraser & $10 \times$ & 2 & $0.41(0.09)$ & n.a. & $86(0.31)$ & $0.16(0.03)$ & $-0.39(0.09)$ \\
\hline
\end{tabular}




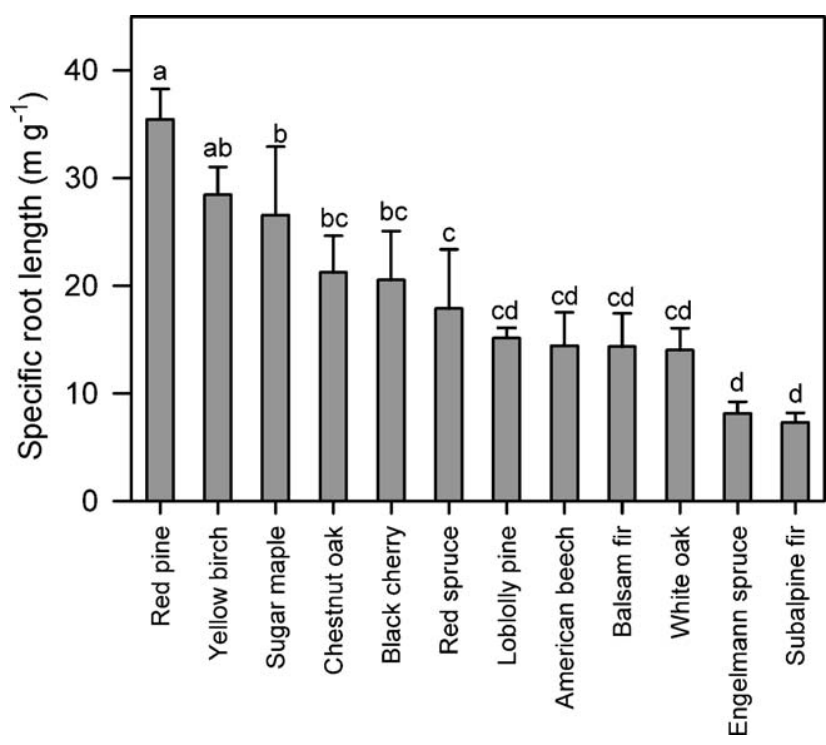

Fig. 4. Specific root length of 12 tree species. Means sharing the same letter do not differ significantly at $\alpha=0.05$.

study (0.1-0.4 $\mu \mathrm{mol} \mathrm{g}_{\mathrm{fwt}}^{-1} \mathrm{~h}^{-1}$ for 2-h experiments, Table 2) was lower than uptake by Norway spruce $\left(0.6 \mu \mathrm{mol} \mathrm{g}_{\mathrm{fwt}}^{-1} \mathrm{~h}^{-1}\right.$, Gessler et al., 1998), sugar maple $\left(0.1-1.1 \mu \mathrm{mol} \mathrm{g}_{\mathrm{fwt}}^{-1} \mathrm{~h}^{-1}\right.$, McFarlane and Yanai, 2006) and American beech $\left(0.5 \mu \mathrm{mol} \mathrm{g}_{\mathrm{fwt}}^{-1} \mathrm{~h}^{-1}\right.$, Gessler et al., $1998)$ trees in the field and loblolly pine $\left(1 \mu \mathrm{mol} \mathrm{g}_{\mathrm{fwt}}^{-1} \mathrm{~h}^{-1}\right.$, Lucash et al., 2008) and Norway spruce seedlings $\left(0.3 \mu \mathrm{mol} \mathrm{g} \mathrm{ftwt}^{-1} \mathrm{~h}^{-1}\right.$, Eltrop and Marschner, 1996) in sand culture. However, McFarlane and Yanai (2006) reported similar $\mathrm{NH}_{4}^{+}$uptake rates by Norway spruce $\left(0.01-0.2 \mu \mathrm{mol} \mathrm{g}_{\mathrm{fwt}}^{-1} \mathrm{~h}^{-1}\right)$ and red pine $\left(0-0.5 \mu \mathrm{mol} \mathrm{g}_{\mathrm{fwt}}^{-1} \mathrm{~h}^{-1}\right)$ to those shown in Table 2 . The same study reported higher $\mathrm{NO}_{3}{ }^{-}$ uptake rates (up to $0.2 \mu \mathrm{mol} \mathrm{g}_{\mathrm{fwt}}^{-1} \mathrm{~h}^{-1}$ for red pine) than were observed in this study $\left(0.02-0.04 \mu \mathrm{mol} \mathrm{g}_{\mathrm{fwt}}^{-1} \mathrm{~h}^{-1}\right)$.

Converted to a dry-weight basis, our $\mathrm{NH}_{4}^{+}$uptake rates $\left(1-2 \mu \mathrm{molg}_{\mathrm{dwt}}^{-1} \mathrm{~h}^{-1}\right)$ were lower than loblolly pine trees in the field (10 $\mu \mathrm{mol} \mathrm{g}_{\mathrm{dwt}}^{-1} \mathrm{~h}^{-1}$, Lucash et al., 2005). Similarly, in solution culture, higher rates of $\mathrm{NH}_{4}^{+}$uptake than those we measured have been reported for seedlings of loblolly pine $\left(10 \mu \mathrm{molg} \mathrm{dwt}^{-1} \mathrm{~h}^{-1}\right.$, Constable et al., 2001), sugar maple ( $16 \mu \mathrm{mol} \mathrm{g}_{\mathrm{dwt}}^{-1} \mathrm{~h}^{-1}$, Rothstein et al., 1996; $8 \mu \mathrm{mol} \mathrm{g} \mathrm{dwt}^{-1} \mathrm{~h}^{-1}$ BassiriRad et al., 1996), American beech ( $9 \mu \mathrm{mol} \mathrm{g}_{\mathrm{dwt}}^{-1} \mathrm{~h}^{-1}$, BassiriRad et al., 1996), and quaking aspen (8-12 $\mu \mathrm{mol} \mathrm{g}_{\mathrm{dwt}}^{-1} \mathrm{~h}^{-1}$, Rothstein et al., 2000). Seedlings of European beech (Fagus sylvatica L.), white ash (Fraxinus americana L.) and willow oak (Quercus phellos L.) had $\mathrm{NH}_{4}^{+}$uptake rates of 15,17 , and $13 \mu \mathrm{mol} \mathrm{g}-1 \mathrm{dwt} \mathrm{h}^{-1}$, respectively, at solution concentrations similar to ours (Lajtha, 1994).

Uptake rates of $\mathrm{Ca}^{2+}, \mathrm{Mg}^{2+}$ and $\mathrm{K}^{+}$were generally similar to other studies. Our $\mathrm{Ca}^{2+}$ uptake rates $\left(1-7 \mu \mathrm{mol} \mathrm{g}_{\mathrm{dwt}}^{-1} \mathrm{~h}^{-1}\right)$ were slightly lower than loblolly pine trees in the field $\left(8 \mu \mathrm{mol} \mathrm{g} \mathrm{dwt}^{-1} \mathrm{~h}^{-1}\right.$, Lucash et al., 2007) and sycamore maple (Acer pseudoplatanus L.) seedlings in hydroponics ( $8 \mu \mathrm{mol} \mathrm{g}_{\mathrm{dwt}}^{-1} \mathrm{~h}^{-1}$, Gloser and Gloser, 2000). Magnesium uptake rates $\left(0.1-1.2 \mu \mathrm{mol} \mathrm{g}_{\mathrm{dwt}}^{-1} \mathrm{~h}^{-1}\right)$ were similar to sycamore maple seedlings in hydroponics $\left(0.2 \mu \mathrm{molg}_{\mathrm{dwt}}^{-1} \mathrm{~h}^{-1}\right.$, Gloser and Gloser, 2000) but lower than loblolly pine trees in the field ( $3 \mu \mathrm{mol} \mathrm{g}-1 \mathrm{dwt}^{-1}$, Lucash et al., 2007). Uptake rates of $\mathrm{K}^{+}$were negative $\left(-0.6\right.$ to $\left.-3.2 \mu \mathrm{molg}_{\mathrm{dwt}}^{-1} \mathrm{~h}^{-1}\right)$ and fell within the large range we found for loblolly pine trees in the field ( -120 to $40 \mu \mathrm{mol} \mathrm{g}_{\mathrm{dwt}}^{-1} \mathrm{~h}^{-1}$, Lucash et al., 2007).

\subsection{Comparison to ecosystem uptake}

Although our rates seem reasonable, or even somewhat low, relative to other reported studies of tree roots, they are quite high compared to the reported ecosystem uptake rates reported for Loch Vale (Arthur and Fahey, 1992). We estimated ecosystem uptake using the mass of roots reported for Loch Vale $\left(900 \mathrm{~g} \mathrm{~m}^{-2}\right.$ for roots $<2 \mathrm{~mm}$; Arthur and Fahey, 1992), our observed uptake rates from $1 \times$ solutions at Loch Vale (Table 2 ), and a conservative estimate of growing season length (150 days, based on temperatures over $0^{\circ} \mathrm{C}$; http://www.wcc.nrcs.usda.gov/climate/foguide.html\#growth). Scaling up our field measurements results in rates at least an order of magnitude higher than needed to explain Arthur and Fahey's (1992) budgeted rates of N (12 times), $\mathrm{Ca}^{2+}$ (60 times) and $\mathrm{Mg}^{2+}$ uptake (19 times too high).

Rates in the field are likely variable over space and time, with high rates, such as those we observed, reserved for roots in particularly favorable environments and seasons. Tree phenology can contribute to temporal variation in nutrient uptake, being higher in loblolly pine seedlings experiencing needle flushing (Kelly and Barber, 1991). Scaling up measurements of nutrient uptake based on seedlings or roots of mature trees in nutrient solutions may give unrealistically high estimates of ecosystem nutrient uptake.

\subsection{Methodological challenges}

We used intact roots in the field to measure nutrient uptake, which we believe should give more realistic estimates than methods involving excised roots or seedlings (Lucash et al., 2007). However, net nutrient efflux, which we observed for $\mathrm{K}^{+}$, is clearly not descriptive of long-term root behavior in nature. We have observed net efflux of $\mathrm{K}^{+}, \mathrm{NH}^{+}, \mathrm{Mg}^{2+}$, and $\mathrm{PO}_{4}{ }^{3-}$ in various forest types using these methods (Lucash et al., 2005, 2007). We also conducted experiments using various pre-treatments to reduce the disturbance to roots of excavating and manipulating them, but failed to eliminate negative rates (McFarlane and Yanai, 2006; Lucash et al., 2008). Potassium is a highly mobile element in plant tissues, and we found net efflux of $\mathrm{K}^{+}$in every ecosystem and every tree species we tested (Lucash et al., 2007). Possible causes besides mechanical disturbance include chemical disturbance and anoxia, though we aerated our solutions and simulated ambient solute concentrations and $\mathrm{pH}$ in our soil solutions. Whatever the mechanism, we believe that it acts sufficiently consistent that our comparisons of sites and species in response to applied nutrient concentrations are valid.

\subsection{Importance of species and site in determining nutrient uptake capacity}

The observation that nutrient uptake rates were more disparate between sites than between species is perhaps the most important result of this study. There are many instances of ecosystem calculations in which some necessary information is unavailable for the site in question. When this is the case, ecosystem scientists commonly substitute values for the relevant species measured at other sites. This problem is not unique to nutrient uptake parameters, and the solution may be different for different types of data. Leaf concentrations, for example, differ significantly by site within species, whereas the mass of leaves may be reasonably predicted by allometric equations not specific to the site (Yanai et al., in prep). For nutrient uptake capacity, our results suggest that site-specific measurements may be important. Higher uptake rates measured at Fraser presumably reflect greater nutrient limitation at Fraser than at Loch Vale.

Engelmann spruce and subalpine fir have similar root morphology. The similarity in specific root length between the two species (Fig. 4) is consistent with their similar nutrient uptake rates. They also had the most similar frequency distribution of root diameters among the 12 tree species we studied (Fig. 5). This 


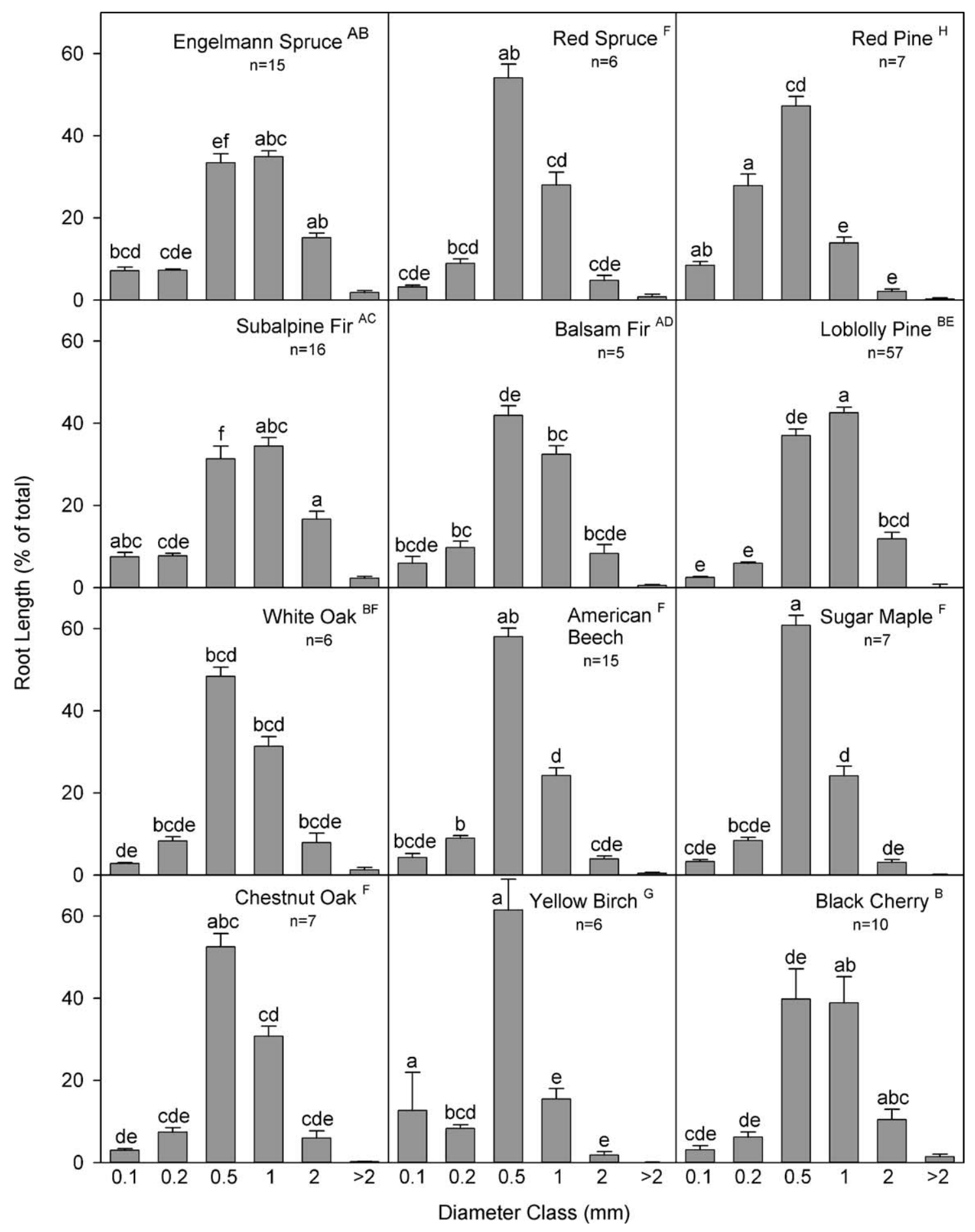

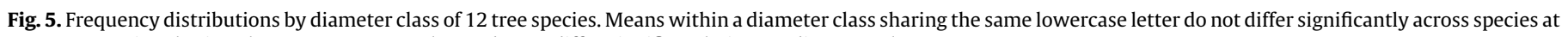
$\alpha=0.05$. Species sharing the same uppercase letter do not differ significantly in any diameter class.

similarity makes it less surprising that the two species do not differ much in nutrient uptake capacity at either site. Similarity in root morphology, however, does not necessarily mean uptake rates will be similar. Root order is a better predictor of root anatomy than root diameter across species (Guo et al., 2008), though no studies to date have linked root order with nutrient uptake of trees. While site was more important than species in this study, we do not suggest that species can always be ignored when estimating nutrient uptake characteristics. Both species characteristics and environmental factors are important to understanding nutrient uptake capacity of trees in field conditions.

\subsection{Recommendations for future research}

There is a need, clearly, for more field studies to compare nutrient uptake capacity of species across a range of environmental conditions. This information will shed light on the differential capability of species to acclimate to past and future conditions, for example under changing atmospheric $\mathrm{N}$ deposition. Selection of species or genotypes for restoration or reforestation projects could benefit from understanding the controls on nutrient uptake capacity. Optimal nutrient management requires predicting nutrient uptake in response to soil amendments. 
Before this information can be used to quantitatively predict uptake at the ecosystem scale, there is also a need for methods that better characterize uptake in field conditions. Our observations of roots exposed for $2 \mathrm{~h}$ to reported soil solution concentrations vastly overestimated annual ecosystem uptake rates, as described above. Although we used intact roots in the field, our method is still unrealistic in that the entire surface area of the roots is in contact with the solution, depletion zones do not form, and mycorrhizal hyphae are disturbed. Seasonal and diurnal patterns in nutrient availability (Kelly, 1993; Kelly and Mays, 1999) and nutrient uptake capacity (Lucash et al., 2005) also deserve more attention.

Nutrient uptake models (Barber, 1984; Yanai, 1994) provide a means for scaling observations of nutrient uptake capacity of individual roots up to the scale of the forest stand. Comparing these estimates to uptake at the ecosystem scale, estimated as the sum of turnover in ephemeral tissues plus accumulation in perennial tissues, could provide a basis for evaluating the realism of techniques for measuring nutrient uptake at the root surface. These comparisons could also help improve our understanding of uptake processes, by revealing the importance of mycorrhizal associations, enhanced mineral weathering, mineralization of organic $\mathrm{N}$ and $\mathrm{P}$, or other processes not currently represented in models of nutrient uptake.

\section{Acknowledgments}

Ruth Sherman helped to develop our approach to measuring nutrient uptake of mature tree roots in the field. Mary Arthur joined us at her site at Loch Vale for field measurements and expressed a healthy skepticism of our methods. Jill Baron provided data, access, and Jorin Botte's guidance in the field at Loch Vale; Robert Stottlemyer provided data, access, and Banning Star's guidance in the field at Fraser. Ruth Sherman and Lisa Montana helped with nutrient analysis, and Heather Engelman and Corrie Blodgett helped prepare the figures. Mike Kelly, Dan Binkley, and two other reviewers provided helpful comments on the manuscript. This project was funded by a National Science Foundation Cross-Site award within the Long-Term Ecological Research program (DEB 0087263).

\section{References}

Alexander, R.R., Troendle, C.A., Kaufmann, M.R., Shepperd, W.D., Crouch, G.L., Watkins, R.K., 1985. Fraser Experimental Froest, Colorado: Research program and published research 1937-1985. General Technical Report, RM-118. US Forest Service, Rocky Mountain Forest and Range Experiment Station, Fort Collins, CO, $46 \mathrm{p}$.

Alstatt, D., Miles, R.L., 1983. Soil Survey of Grand County Area, Colorado USDA Soil Conservation Service and Forest Service and Colorado Agriculture Experiment Station. U.S. Government Printing Office.

Arthur, M.A., 1992. Vegetation. In: Baron, J. (Ed.), Biogeochemistry of a Subalpine Ecosystem: Loch Vale Watershed. Ecological Studies Series 90. Springer-Verlag, NY.

Arthur, M.A., Fahey, T.J., 1992. Biomass and nutrients in an Engelmann sprucesubalpine fir forest in north-central Colorado: pools, annual production and internal cycling. Canadian Journal of Forest Research 22, 315-325.

Arthur, M.A., Fahey, T.J., 1993. Controls on soil solution chemistry in a subalpine forest in north-central Colorado. Soil Science Society of America Journal 57 $1122-1130$.

Barber, S.A., 1984. Soil Nutrient Bioavailability: A Mechanistic Approach. John Wiley and Sons, Inc., New York.

Baron, J.S., Rueth, H.M., Wolfe, A.M., Nydick, K.R., Allstott, E.J., Minear, T., Moraska, B., 2000. Ecosystem responses to nitrogen deposition in the Colorado Front Range. Ecosystems 3, 352-368.

BassiriRad, H., Thomas, R.B., Reynolds, J.F., Strain, B.R., 1996. Differential responses of root uptake kinetics of $\mathrm{NH}_{4}{ }^{+}$and $\mathrm{NO}_{3}{ }^{-}$to enriched $\mathrm{CO}_{2}$ concentration in fieldgrown loblolly pine. Plant, Cell \& Environment 19, 367-371.

Bouma, T.J., Eissenstat, D.M., Yanai, R.D., Elkin, A., Hartmond, U., Flores, D., 2001 Estimating age-dependent costs and benefits of roots with contrasting lifespan: comparing apples and oranges. New Phytologist 150, 685-695.
Campbell, D.H., Baron, J.S., Tonnessen, K.A., Brooks, P.D., Schuster, P.F., 2000. Controls on nitrogen flux in alpine/subalpine watersheds of Colorado. Water Resources Research 36, 37-47.

Chapin, F.S.I., Van Cleve, K., Tryon, P.R., 1986. Relationship of ion absorption to growth rate in taiga trees. Oecologia 69, 238-242.

Constable, J.V.H., BassiriRad, H., Lussenhop, J., Zerihun, A., 2001. Influence of elevated $\mathrm{CO}_{2}$ and mycorrhizae on nitrogen acquisition: contrasting responses in Pinus taeda and Liquidambar styraciflua. Tree Physiology 21, 83-91.

Eissenstat, D.M., 1992. Costs and benefits of constructing roots of small diameter. Journal of Plant Nutrition 15, 763-782.

Eltrop, L., Marschner, H., 1996. Growth and mineral nutrition of non-mycorrhizal and mycorrhizal Norway spruce (Picea abies) seedlings grown in semi-hydroponic sand culture. I. Growth and mineral nutrient uptake in plants supplied with different forms of nitrogen. New Phytologist 133, 469-478.

Fahey, T.J., Hughes, J.W., 1994. Fine root dynamics in a northern hardwood forest ecosystem, Hubbard Brook Experimental Forest. Journal of Ecology 82, 533548.

Fenn, M.E., Haeuber, R., Tonnesen, G.S., Baron, J.S., Grossman-Clarke, S., Hope, D., Jaffe, D.A., Copeland, S., Geiser, L., Rueth, H.M., Sickman, J.O., 2003. Nitrogen emissions, deposition, and monitoring in the western United States. BioScience 53, 391-403.

Gessler, A., Schneider, S., Von Sengbusch, D., Weber, P., Hanemann, U., Huber, C., Rothe, A., Kreutzer, K., Rennenberg. H., 1998. Field and laboratory experiments on net uptake of nitrate and ammonium by the roots of spruce (Picea abies) and beech (Fagus sylvatica) trees. New Phytologist 138, 275-285.

Gloser, V., Gloser, J., 2000. Nitrogen and base cation uptake in seedlings of Acer pseudoplatanus and Calamagrostis villosa exposed to an acidified environment. Plant and Soil 226, 71-77.

Guo, D., Xia, M., Wei, X., Chang, W., Liu, Y., Wang, Z., 2008. Anatomical traits associated with absorption and mycorrhizal colonization are linked to root branch order in twenty-three Chinese temperate tree species. New Phytologist 180, 673-683.

Högberg, P., Högbom, L., Schinkel, H.A., 1998. Nitrogen-related root variables of trees along an N-deposition gradient in Europe. Tree Physiology 18, 823-828.

Jones, H.E., Högberg, P., Ohlsson, H., 1994. Nutritional assessment of a forest fertilization experiment in northern Sweden by root bioassays. Forest Ecology Management 64, 59-69.

Kelly, J.M., 1993. Temperature affects solution-phase nutrient concentrations and subsequent calculations of supply parameters. Soil Science Society of America Journal 57, 527-531.

Kelly, J.M., Barber, S.A., 1991. Magnesium uptake kinetics in loblolly pine seedlings. Plant and Soil 134, 227-232.

Kelly, J.M., Mays, P.A., 1999. Nutrient supply changes within a growing season in two deciduous forest soils. Soil Science Society of America Journal 63, 226-232.

Lajtha, K., 1994. Nutrient uptake in eastern deciduous tree seedlings. Plant and Soil 160, 193-199.

Lee, R.B., Rudge, K.A., 1986. Effects of nitrogen deficiency on the absorption of nitrate and ammonium by barley plants. Annals of Botany 57, 471-486.

Lucash, M.S., Eissenstat, D.M., Joslin, J.D., McFarlane, K.J., Yanai, R.D., 2007. Estimating nutrient uptake by mature tree roots under field conditions: challenges and opportunities. Trees-Structure and Function 21, 593-603.

Lucash, M.S., Yanai, R.D., Joslin, J.D., 2008. Nutrient uptake by intact and disturbed roots of loblolly pine seedlings. Environmental and Experimental Botany 64, 15-20.

Lucash, M.S., Yanai, R.D., Joslin, J.D., 2005. Temporal variation in nutrient uptake capacity by intact roots of mature loblolly pine. Plant and Soil 272, 253-262.

McFarlane, K.J., Yanai, R.D., 2006. Measuring nitrogen and phosphorus uptake by intact roots of mature Acer saccharum Marsh., Pinus resinosa Ait., and Picea abies (1.) Karst. Plant and Soil 279, 163-172.

Retzer, J.L., 1962. Soil Survey of Fraser Alpine Area, Colorado. Soil Surv. Serv. 1956, No. 20. USDA Soil Conservation Service, Washington, DC, 47 p.

Rothstein, D.E., Zak, D.R., Pregitzer, K.S., 1996. Nitrate deposition in northern hardwood forests and the nitrogen metabolism of Acer saccharum marsh. Oecologia 108, 334-338.

Rothstein, D.E., Zak, D.R., Pregitzer, K.S., Curtis, P.S., 2000. Kinetics of nitrogen uptake by Populus tremuloides in relation to atmospheric $\mathrm{CO}_{2}$ and soil nitrogen availability. Tree Physiology 20, 265-270.

Rueth, H.M., Baron, J.S., 2002. Differences in Engelmann spruce forest biogeochemistry east and west of the Continental Divide in Colorado, USA. Ecosystems 5 45-57.

SAS Institute, Inc., 2004. SAS User's Guide: Statistics. Version 9.00. SAS Institute, Inc., Cary, NC.

Siddiqi, M.Y., Glass, A.D.M., Ruth, T.J., Fernando, M., 1989. Studies of the regulation of nitrate influx by barley seedlings using ${ }^{13} \mathrm{NO}_{3}{ }^{-}$. Plant Physiology $90,1426-$ 1432.

Stottlemyer, R., Troendle, C.A., 1992. Nutrient concentration patterns in streams draining alpine and subalpine catchments, Fraser Experimental Forest, Colorado. Journal of Hydrology 140, 179-208.

Stottlemyer, R., Troendle, C.A., Markowitz, D., 1997. Change in snowpack, soil water, and streamwater chemistry with elevation during 1990, Fraser Experimental Forest, Colorado. Journal of Hydrology 195, 114-136.

Yanai, R.D., 1994. A steady-state model of nutrient uptake improved to account for newly-grown roots. Soil Science Society of America Journal 8, 1562-1571. 